Polonistyka. Innowacje

Numer 1, 2015

DOI: $10.14746 /$ pi.2015.1.1.5

\begin{abstract}
Anna Tabisz
Uniwersytet Opolski
\end{abstract}

\title{
Czy szkoła uczy mówienia? O ustnych wypowiedziach gimnazjalistów
}

\author{
Does school teach speaking? - about junior high school students' speeches
}

\begin{abstract}
The article consists of two sections. In the first part of the article the author discusses the aim and course of the study on the level of mastery by junior high school students their ability to create a coherent monologue, oral statements and the author presents results that indicate that the students do not succeed satisfactory in speaking out. The most difficult point for the tested students was, as it turned out, talking in a comprehensive manner and building consistent and orderly expressions. Interestingly, rhetorical aspect was made slightly better. In the second part of the article the author is trying to identify the reasons for poor control of speaking (limited to the factors of school). These include the abuse on Polish language lessons, the usage of heuristic methods, as well as the absence of tasks in textbooks for teaching Polish aiding the improvement of speaking skills.
\end{abstract}

Keywords: developing communicative competence, speaking skills.

W wielu sytuacjach życiowych kompetencja mówienia odgrywa ogromną rolę. Umiejętność płynnego, logicznego wypowiadania się na różne tematy, bycie przekonującym dyskutantem, interesującym i uczciwym partnerem w rozmowie może decydować o satysfakcjonującej ocenie w szkole, wysokiej nocie na dyplomie wyższych studiów, zdobyciu wymarzonego miejsca pracy czy szacunku wśród znajomych - ogólnie rzecz biorąc - o sukcesie w życiu. Warto więc zastanowić się, czy w szkole uczy się mówienia?

\section{Sprawność mówienia w dokumentach szkolnych}

Czytając współczesne dokumenty programowe, można dostrzec, że szkoła w istocie zwraca się „Ku sztuce poprawnego, sprawnego, skutecznego i pięknego posługiwania się 
językiem [...]" (Kowalikowa 2001, 512). Z zapisów w podstawie programowej nauczania języka polskiego (2008) wynika, że na każdym z etapów edukacyjnych doskonalenie kompetencji komunikacyjnej stało się kluczowe, a poszczególne sprawności, w tym sprawność mówienia, z jednej strony są potraktowane ,jako składnik wykształcenia ogólnego, [...], element kultury osobistej, niejako bezinteresownie stosowanej w komunikacji społecznej" (Zgółkowa 2001, 493), z drugiej strony jako swoiste „wyposażenie”, którego przydatność jest wyznaczona przyszłymi potrzebami zawodowymi, specjalizacją akademicką czy zawodową realizowaną po zakończeniu edukacji gimnazjalnej i licealnej (Zgółkowa 2001, 493).

Umiejętność mówienia jest kategorią złożoną, na którą składają się takie aspekty, jak: merytoryczny, retoryczny, interakcyjny, kompozycyjny, stylowy, językowy, etykietalny, etyczny oraz niewerbalny. Przykładowe treści związane z kształceniem kompetencji mówienia na poziomie gimnazjum ${ }^{1}$ prezentuje tabela 1.

\begin{tabular}{|l|l|}
\hline \multicolumn{1}{|c|}{ Aspekt } & \multicolumn{1}{|c|}{ Zapis z podstawy programowej } \\
\hline merytoryczny & tworzy [...] wypowiedź na zadany temat; \\
\hline retoryczny & uzasadnia własne zdanie, przyjmuje poglądy innych lub polemizuje z nimi; \\
\hline interakcyjny & uczestniczy w dyskusji; \\
\hline kompozycyjny & $\begin{array}{l}\text { tworzy spójne wypowiedzi ustne [...] w następujących formach gatunkowych } \\
{[\ldots] ; \text { stosuje zasady organizacji tekstu zgodnie z wymogami gatunku, tworząc }} \\
\text { spójną pod względem logicznym i składniowym wypowiedź [...]; }\end{array}$ \\
\hline stylowy & $\begin{array}{l}\text { dostosowuje odmianę i styl języka do gatunku, w którym się wypowiada; } \\
\text { tworząc wypowiedzi, dąży do precyzyjnego wysławiania się; }\end{array}$ \\
\hline językowy & $\begin{array}{l}\text { świadomie dobiera synonimy i antonimy dla wyrażenia zamierzonych treści, } \\
\text { stosuje różne rodzaje zdań we własnych tekstach; operuje słownictwem } \\
\text { z określonych kręgów tematycznych [...]; }\end{array}$ \\
\hline $\begin{array}{l}\text { stosuje zasady etykiety grzecznościowej - wie, w jaki sposób zwracać się } \\
\text { do rozmówcy w zależności od sytuacji i relacji [...]; zna formuły } \\
\text { grzecznościowe, zna konwencje językowe zależne od środowiska, } \\
\text { ma świadomość konsekwencji używania formuł niestosownych i obraźliwych; }\end{array}$ \\
\hline etykietalny & $\begin{array}{l}\text { przestrzega zasad etyki mowy w różnych sytuacjach komunikacyjnych; } \\
\text { interpretuje głosowo wybrane utwory literackie. }\end{array}$ \\
\hline etyczny &
\end{tabular}

Tabela 1. Treści związane z kształceniem kompetencji mówienia na poziomie gimnazjum (Podstawa programowa 2008).

\footnotetext{
${ }^{1} \mathrm{~W}$ dalszej części artykułu powołuję się na badania przeprowadzone w grupie gimnazjalistów, stąd ograniczam się do podania treści związanych z kształceniem sprawności mówienia na III etapie edukacyjnym.
} 
Obok zapisów w dokumentach programowych mamy szkolną rzeczywistość. $\mathrm{Z}$ różnych powodów (o nich w końcowej części artykułu) systematyczne i przemyślane rozwijanie umiejętności mówienia w szkole - jeżeli nie jest zaniedbywane - to z pewnością nie jest traktowane priorytetowo.

W dalszej części artykułu chciałabym przedstawić wyniki badania umiejętności mówienia, wykonanego w ramach projektu Instytutu Badań Edukacyjnych pn. Dydaktyka literatury i języka polskiego $w$ gimnazjum $w$ świetle nowej podstawy programowej, a także zaproponować kilka hipotez wyjaśniających owe wyniki.

\title{
Cel i przebieg badania
}

Celem badania było rozpoznanie, w jakim stopniu gimnazjaliści opanowali umiejętność tworzenia spójnej ustnej wypowiedzi monologowej, a w szczególności, biorąc pod uwagę złożoność tej kategorii, znalezienie odpowiedzi na pytania, czy uczniowie gimnazjum:

- mówią na temat i na ile ten temat potrafią rozwinąć?;

- potrafią budować wypowiedź spójną i uporządkowaną?;

- opanowali umiejętności retoryczne (argumentowanie i uzasadnianie wypowiedzi)?;

- znają specjalistyczną terminologię i stosują ją we własnej wypowiedzi?;

- stosują się do normy języka mówionego, jaki jest styl i język ich wypowiedzi?;

- potrafią świadomie wykorzystywać środki pozawerbalne?

W badaniu prowadzonym w sześciu szkołach metodą indywidualnych wywiadów pogłębionych brało udział 60 gimnazjalistów ( 28 dziewcząt i 32 chłopców) osiągających zarówno bardzo dobre, jak i słabe wyniki w nauce. Podczas rozmowy z moderatorem uczniowie otrzymali zadanie:

\begin{abstract}
Chciał(a)bym lepiej poznać twoje zainteresowania i upodobania związane z językiem polskim. Dlatego na początku poproszę cię o krótką wypowiedź, trwającą 3-5 minut, o ulubionej książce lub ulubionym filmie/przedstawieniu teatralnym, dziele sztuki (obrazie, rzeźbie, budynku) / muzyce (piosence)/ grze komputerowej itp. Przedstaw wybrany tekst oraz powiedz, za co go lubisz.
\end{abstract}

Nagrana na dyktafon wypowiedź analizowana była pod kątem sześciu aspektów: merytorycznym; retorycznym, kompozycyjnym; stylowym, językowym i niewerbalnym ${ }^{2}$. Do opisu wykonania każdego z aspektów wykorzystano trzystopniową skalę, w której 2 punkty świad-

\footnotetext{
${ }^{2}$ Analizowana była wypowiedź monologowa, dlatego trzy aspekty: interakcyjny, etykietalny i etyczny zostały pominięte.
} 
czyły o pełnym opanowaniu kompetencji ocenianej w danym aspekcie, 1 punkt oznaczał częściowe opanowanie kompetencji w danym aspekcie, a 0 poziom wykonania świadczący o nieopanowaniu kompetencji w danym aspekcie.

\section{Prezentacja wyników ogólnych}

$\mathrm{Na}$ wykresie 1. uwzględniono dane procentowe obrazujące poziom wykonania każdego $\mathrm{z}$ aspektów z podziałem na pięć grup: cała grupa, dziewczęta, chłopcy, zdolni i słabi uczniowie.

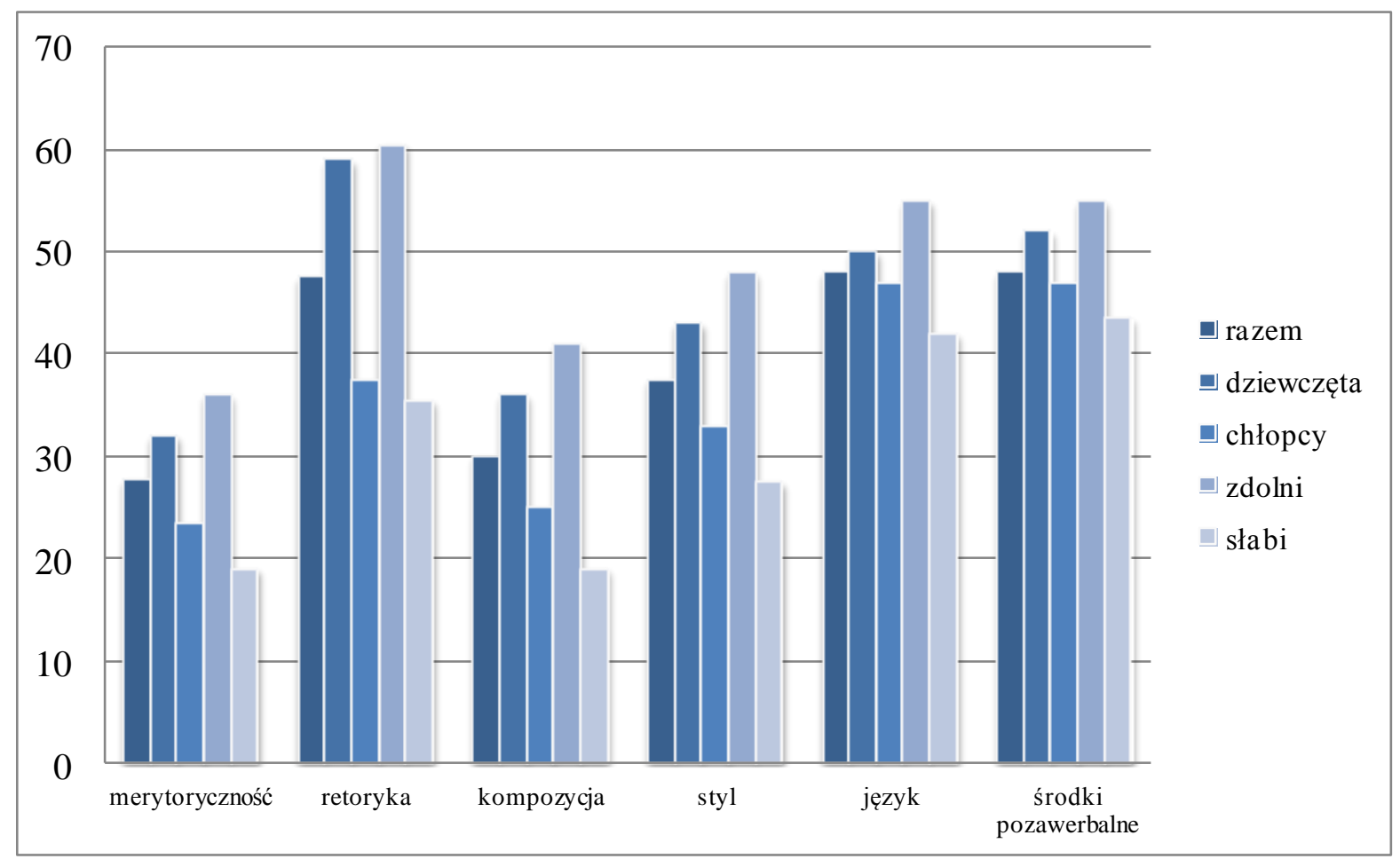

Wykres 1. Realizacja aspektów mówienia w poszczególnych grupach.

Zestawione wyniki pokazują, że umiejętność tworzenia spójnej ustnej wypowiedzi monologowej opanowana jest częściowo. Najtrudniejsze do zrealizowania okazały się aspekty merytoryczny i kompozycyjny, nieco lepiej wypadł aspekt retoryczny. Średnia arytmetyczna wyników całej grupy wynosi blisko 5 punktów (na 12 punktów możliwych do uzyskania), przy czym wyższy poziom umiejętności tworzenia dłuższej wypowiedzi ustnej reprezentują dziewczęta, na co prawdopodobnie miała wpływ nierównomierność badanej próby. Wśród dwudziestu ośmiu gimnazjalistek dwadzieścia trzy zostały scharakteryzowane przez polonistów jako uczennice bardzo dobre, z kolei wśród trzydziestu dwóch gimnazjalistów dwudziestu pięciu zostało uznanych przez nauczycieli jako uczniowie słabi, stąd trudno wyciągać 
wniosek o istotnej różnicy jakościowej w tworzeniu ustnej wypowiedzi monologowej na zadany temat między dziewczętami a chłopcami, ponieważ we wszystkich aspektach można dostrzec zbieżność wyników w grupie dziewcząt i uczniów zdolnych oraz w grupie chłopców i uczniów słabych.

\section{Prezentacja wyników szczegółowych}

\section{Aspekt merytoryczny}

Możliwość wyboru tekstu kultury pozostawiona w temacie ,[...] Przedstaw wybrany tekst oraz powiedz, za co go lubisz" miała sprzyjać stworzeniu sytuacji, w której uczeń ma coś do powiedzenia, a temat go nie przerasta. Okazało się jednak, że ponad połowa uczniów nie potrafiła w sposób zadowalający zrealizować tego aspektu. Przykładowo ${ }^{3}$ :

\footnotetext{
Na przykład teraz na święta dostałam taką trylogię / takie książki trzy / no i zaczęłam ją czytać / yyy to jest opowieść takiej dziewczyny i chłopaka / on jest jakby wilkiem tak / yyy to jest literatura fantastyczna / no i dziewczyna opowiada jak właśnie kiedyś była ugryziona przez wilki / teraz jej chłopak się zmienia /oni są razem / razem wszystko robią / chodzą po mieście / ona razem z nim mieszka //
}

Wypowiedź jest zgodna $\mathrm{z}$ tematem, jednak jej rozwinięcie jest niedostateczne. Przyczyną ubogiej treści wypowiedzi może być brak rzetelnej wiedzy na temat wybranego tekstu kultury. Ogólnikowy, powierzchowny sposób rozwijania tematu stanowi „parawan osłaniający ubóstwo wiadomości rzeczowych oraz brak konkretnych przemyśleń i refleksji” (Kaniewska 1987, 27) ucznia jako odbiorcy tekstu kultury. Mówiąca wykorzystała strategię opartą na „prawidłowej, właściwej zachowaniu człowieka operacji, która stanowi zamianę tego, co przerasta ich możliwości, w to, co potrafią" (Wiśniewska 2001, 129). Dlatego wywód argumentacyjny przerodził się w krótkie i zdawkowe streszczenie tekstu. Jedynie sześcioro badanych posiadało wystarczającą wiedzę na temat prezentowanego tekstu, dzięki czemu szczegółowo wypowiadali się na jego temat.

O nieumiejętności rozwijania tematu może również świadczyć czas samej wypowiedzi przedstawiony na wykresie 2 . Ponad $60 \%$ gimnazjalistów nie było w stanie wypowiadać się dłużej niż dwie minuty. Wydaje się, iż uczniowie nie mieli wypracowanego paradygmatu działania, który umożliwiłby mówienie według przyjętego planu, co często doprowadzało do zakończenia zadania przed założonym czasem.

\footnotetext{
3 Zapis wypowiedzi pozbawiony jest znaków interpunkcyjnych, jeden ukośnik oznacza krótką pauzę, dwa ukośniki długą pauzę.
} 


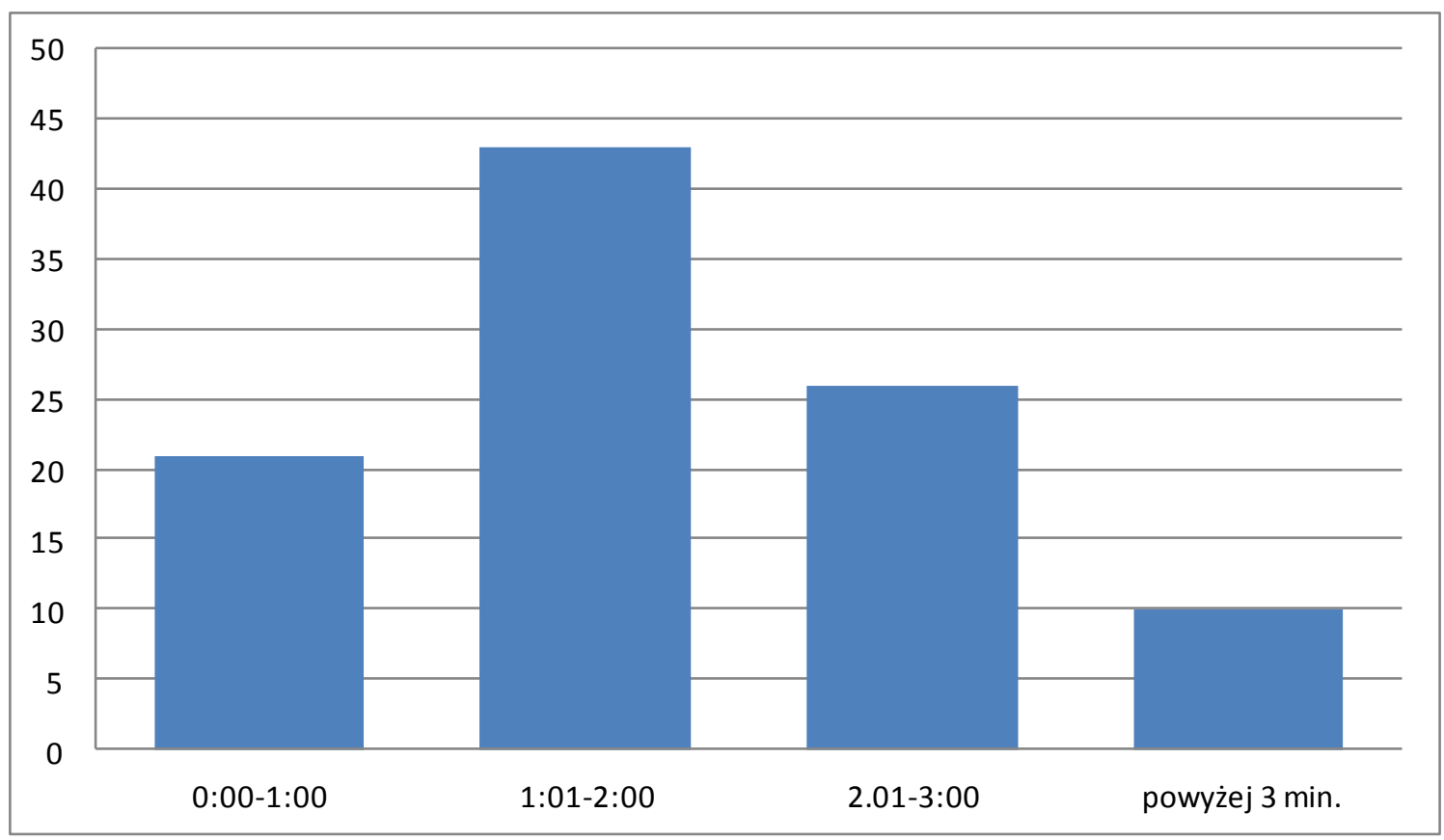

Wykres 2. Czas trwania wypowiedzi monologowej podany w minutach.

Interesujący jest również wybór tekstów kultury dokonywany przez mówiących (zob. wykres 3.). Blisko połowa badanych uczniów wykorzystała w wypowiedziach tekst literacki. Być może, wbrew powszechnym sądom, czytanie książek wśród nastolatków jest dość popularne. Na wybór tego typu tekstu mógł jednak wpłynąć kontekst sytuacyjny - uczeń wypowiadał się w klasie, a przeprowadzany wywiad, w czasie którego wykonywane było zadanie, dotyczył lekcji języka polskiego, dla którego centralnym tekstem jest tekst literacki. Młodzież sięgała zarówno po teksty pozaszkolne przede wszystkim z kręgu kultury popularnej (dużą popularnością - zwłaszcza wśród dziewcząt - cieszyła się seria Zmierzch Stephenie Meyer), jak i po utwory z listy lektur (seria Harry Potter Joanny K. Rowling). Wśród słabszych uczniów obserwowalna była tendencja sięgania po klasyczne lektury, np. Dziady Adama Mickiewicza, Zemstę Aleksandra Fredry, Balladynę Juliusza Słowackiego. Poniżej przykład wypowiedzi prezentującej ostatnią z lektur:

Balladyna mówi o tym / hyy że miała / hyy Balladyna / to była siostra hyy i hyy jak ona miała / zapomniałam jak ta druga siostra miała na imię / to że Balladyna zabiła swoją siostrę / dlatego / że / hyy żeby mieć więcej malin od niej / żeby tak hyy / żeby więcej / żeby dostać ten / męża / czyli księcia / żeby być królową / i została królową / zabiła swoją siostrę / zabrała jej maliny / hyy i nie wiem. 


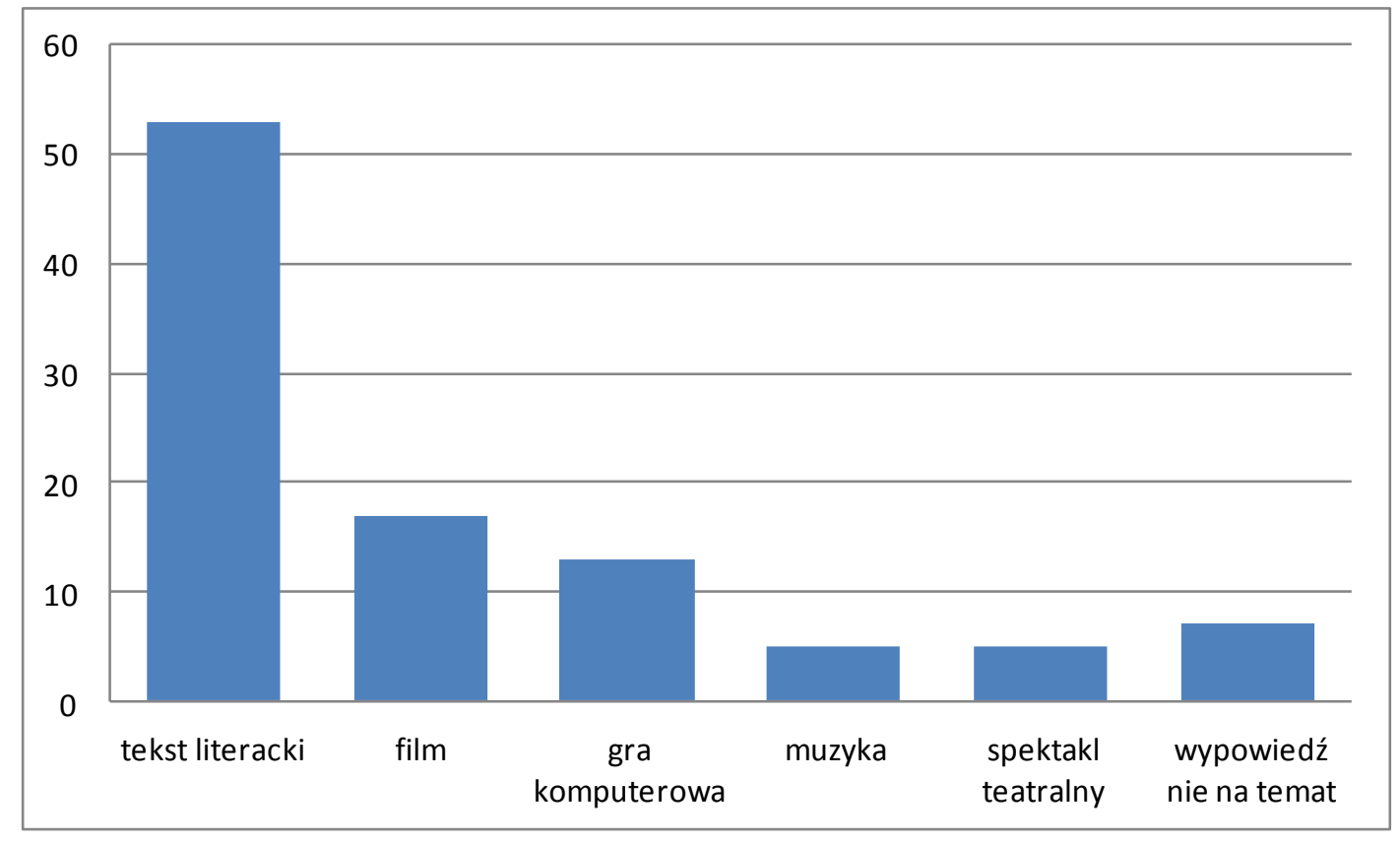

Wykres 3. Rodzaj tekstów kultury przywoływanych w wypowiedziach.

\section{Aspekt retoryczny}

Realizacja aspektu retorycznego wiąże się $\mathrm{z}$ umiejętnością wyrażania własnego zdania, stosunku do tego, co się mówi, formułowania własnych opinii i ocen. Kryterium nie było zaliczane, jeżeli autor wypowiedzi posługiwał się $\mathrm{w}$ niej argumentami emocjonalnymi lub pomimo prośby o wypowiedzenie własnego sądu na temat wybranego tekstu kultury nie podejmował zadania, a co najwyżej stwierdzał: podoba mi się.

Aspekt retoryczny wypowiedzi był wykonany przez badanych znacznie lepiej niż aspekt merytoryczny. Blisko 65\% gimnazjalistów podawało co najmniej jeden argument, dlaczego wybrany tekst jest ich ulubionym, jednak jedynie 13\% potrafiło rozwinąć swą argumentację, przywołując więcej niż jeden argument i szerzej uzasadniając swój wybór. Na lepszy wynik uzyskany w tym obszarze mogła mieć wpływ możliwość zadawania przez moderatora dodatkowych pytań, wśród których najczęściej pojawiały się prośby: „A dlaczego ten rodzaj muzyki?”, „A dlaczego ta książka tak ci przypasowała?”, „A dlaczego byś tę książkę poleciła?”, „A dlaczego warto ją przeczytać?”. Większość odpowiedzi na tak postawione pytanie przybierała postać rzeczowego prostego argumentu wraz z krótkim uzasadnieniem, np.:

[...] najlepiej mi się właśnie podoba gatunek muzyki rap / bo śpiewają bardzo bardzo prawdziwe teksty;

No jest spisana takim luźnym językiem / bardzo przyjemnie się ją czyta. 
Wydaje się, że największą świadomość retoryczną reprezentowali ci uczniowie, którzy argumentowali swój wybór bez pomocniczych pytań, a ich wypowiedź miała charakter ciągły (20\%). Pozostali badani wspomagani byli jednym (49\%) lub dwoma i więcej pytaniami $(31 \%)$. Obrazuje to wykres 4.

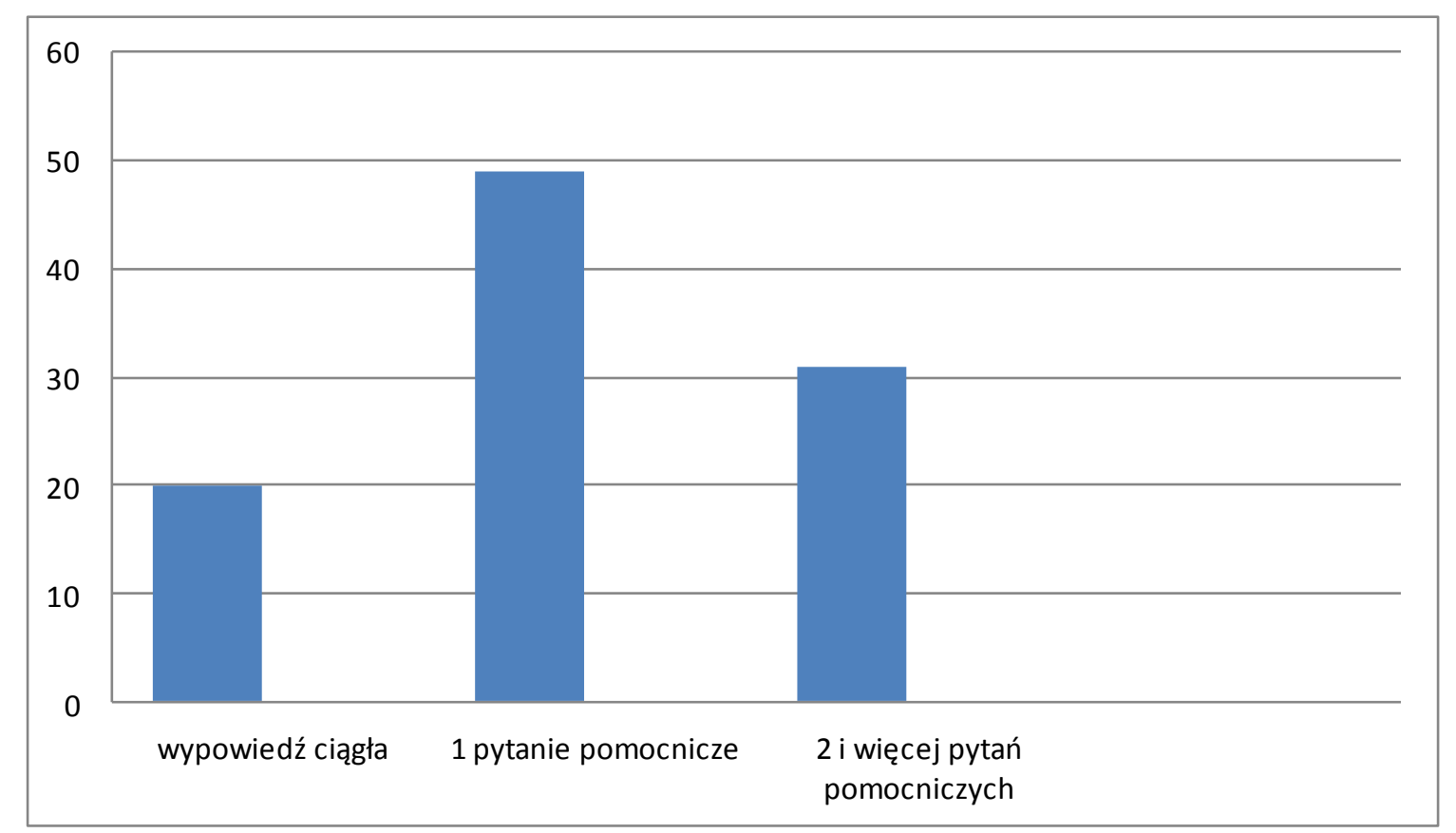

Wykres 4. Ciągłość ustnej wypowiedzi monologowej.

\section{Aspekt kompozycyjny}

Biorąc pod uwagę zaproponowany temat wypowiedzi, można było oczekiwać, iż tekst gimnazjalistów o charakterze prezentacyjno-argumentacyjnym będzie zawierał następujące elementy kompozycyjne: we wstępie - uwagi wprowadzające (np. określenie tematu wypowiedzi, wybór tekstu kultury); w rozwinięciu - część prezentacyjną obejmującą różne informacje na temat przedstawianego tekstu kultury (np. krótkie streszczenie fabuły czy opis w przypadku dzieła malarskiego) oraz część argumentacyjną posiłkującą się co najmniej jednym argumentem uzasadniającym i elementami służącymi do identyfikacji przesłanek i konkluzji (bo, ponieważ, a zatem, więc itp.); w zakończeniu - refleksje i stosunek mówiącego do przedstawianego tekstu kultury.

Blisko połowa badanych gimnazjalistów (48\%) nie zdołała skomponować w przemyślany i uporządkowany sposób swojej wypowiedzi. Słuchając ich, odnosiło się wrażenie, że mówili to, co w danej chwili przyszło im na myśl. Można sądzić, że większość uczniów nie ma świadomości, iż „Wybór i kolejność podawanych treści, myśli i argumentów, odpowiedni układ i porządek wprowadzania kolejnych elementów oraz ich dostosowanie do okoliczności 
[...] są czynnikami wpływającymi na skuteczność [...]” (Szymanek 2012, 171) wypowiedzi argumentacyjnej.

Dla wielu uczniów kłopotliwe okazało się stosowanie tranzycji wskazujących przechodzenie do kolejnych części wystąpienia. Tworzą one uchwytne „dla ucha” ramy wypowiedzi, „organizują przestrzeń tekstową, wytyczają jej punkty strategiczne, a tym samym pozwalają odbiorcy ustalać, w jakim miejscu się znajduje i w jaką stronę powinien zmierzać, dążąc do całościowej interpretacji danego zdarzenia tekstowego" (Duszak 1998, 127). Brak wyraźnych tranzycji w wypowiedziach zakłócał właściwą interpretację wewnętrznych elementów kompozycyjnych tekstu.

\section{Aspekt stylowy}

Wypowiedzi 30\% uczniów miały charakter „bezstylowy” i charakteryzowały się tzw. ,prymitywizmem językowym”. Przykładowo:

no to lubię czytać książki romantyczne [...] są tam różne słownictwo w książkach można je poznać/ hyy / no i wywierają różne emocje / czyli są wciągające hyy// ale są długie też / bo długo się też czyta / zaraz się nie skończą i trzeba kupować nowe / no / no/ i tak się można długo wciągać /hyy tak właściwie tak się czyta różne emocje wywiera książka//

Styl cytowanej wypowiedzi jest nieprecyzyjny i pozbawiony rzeczowości, przywołany fragment posiada znamiona kodu ograniczonego, zarówno na poziomie składniowym (proste, powtarzające się struktury syntaktyczne), jak i leksykalnym (ubogie słownictwo, brak synonimii, abstrakcyjnych pojęć czy terminów). Jedynie troje uczniów otrzymało za ten aspekt wypowiedzi maksymalną liczbę punktów. Pozostali badani (65\%) uzyskali co najmniej jeden punkt, co oznacza, iż ich wypowiedź była dostosowana do sytuacji i posiadała cechy kodu rozwiniętego. Gimnazjaliści posługiwali się podstawowym słownictwem z rejestru polszczyzny ogólnej, natomiast prawie $\mathrm{w}$ ogóle nie stosowali $\mathrm{w}$ swoich wypowiedziach terminów.

\section{Aspekt językowy}

Niewielu uczniów posługiwało się językiem właściwym dla normy wzorcowej. Niemalże wszyscy badani gimnazjaliści (93\%) wypowiadali się językiem zgodnym z normą użytkową. Przykładowo: 
To jest książka /seria książek australijskiego autora / nazywa się „Zwiadowcy”/ to jest książka fantasy która opowiada o losach i przygodach takiej elitarnej grupy ludzi / którzy działają na rzecz państwa / dowiadują się różnych informacji / działają w sumie tak skrycie / ale za to są bardzo inteligentni / dobrze do tego przygotowani / książka mi się bardzo podoba / ponieważ to jest taki świat / w którym wszystko jest albo czarne albo białe//

Być może na taki wynik miał wpływ kontekst sytuacyjny. $Z$ jednej strony uczeń wypowiadał się w klasie w obecności dorosłej, obcej osoby, z drugiej z kolei moderator starał się łagodzić oficjalność sytuacji. Wydaje się, iż w takiej sytuacji komunikacyjnej akceptowalne jest stosowanie normy potocznej ogólnej, która stanowi trzon normy użytkowej. Jest ona charakterystyczna dla języka potocznego i według Jerzego Podrackiego „duża część środków językowych, podawanych jako ilustracja tej normy, stanowi obecnie de facto składnik normy wzorcowej (w każdym razie powszechnego uzusu, także ludzi wykształconych)" (Podracki 2013, 17).

\section{Aspekt pozawerbalny}

Poprawne wykonanie tej kategorii polega na świadomym wykorzystaniu środków pozawerbalnych w celu podkreślenia treści wypowiedzi. Służą temu odpowiednie tempo, stosowny akcent logiczny czy intonacja (przy ocenie tego kryterium nie brano pod uwage zaburzeń artykulacyjnych spowodowanych wadami wymowy czy noszeniem przez ucznia aparatu ortodontycznego). Ponad 90\% badanych uczniów otrzymało za ten aspekt jeden punkt, ponieważ sposób artykułowania oraz tempo mówienia nie zakłócały odbioru wypowiedzi. Nie znaczy to, iż teksty gimnazjalistów pozbawione były błędów.

Wśród najliczniejszych mankamentów pojawiających się w wypowiedziach badanych znalazły się usterki fonetyczne polegające na uproszczeniach grup spółgłoskowych, uproszczeniach związanych $\mathrm{z}$ artykulacją głoski $\ell \mathrm{w}$ śródgłosie, dekompozycją samogłoski nosowej $a \mathrm{w}$ wygłosie. Inne tendencje prozodyczne to stosowanie niewłaściwej intonacji - bez względu na typ wypowiedzenia badani dość powszechnie wykorzystywali antykadencję; nieumiejętne stosowanie akcentu logicznego w charakterze środka wzmacniającego treść wypowiedzi, nieobecność pauz gramatycznych wspomagających odbiorcę w porządkowaniu przestrzeni tekstowej. Pojawiały się natomiast liczne pauzy niegramatyczne określane mianem przerwań (Śniatkowski 2002, 19), będące dowodem niezdecydowania, namysłu mówiącego. Najczęściej pauzy tego typu były wypełnione ciągami fonicznymi nieleksykalnymi typu $e, y, h m, a$. Choć nie są one miłe dla ucha, Sławomir Śniatkowski zwraca uwagę, 
że stosowanie pauz wypełnionych staje się nawykiem mownym, a decydującym czynnikiem ich powstawania jest ,świadomość mówiącego, że wypowiedź jest ciągiem brzmieniowym: zbyt długie i zbyt częste momenty ciszy mogą utrudniać, a nawet uniemożliwić właściwy odbiór tekstu mówionego (Śniatkowski 2002, 16).

\section{Dlaczego uczniowie nie potrafią wypowiedzieć się na zadany temat?}

Stopnia opanowania przez gimnazjalistów umiejętności tworzenia dłuższej wypowiedzi monologowej nie można uznać za zadowalający. Przyczyny tego stanu rzeczy mogą być rozmaite, warto pamiętać, iż prawidłowy przebieg rozwoju mowy uwarunkowany jest wieloma czynnikami, zarówno zewnętrznymi, jak i wewnętrznymi (osobistymi) (szerzej na ten temat zob. Tabisz 2013). Tutaj chciałabym się skupić na kilku wybranych czynnikach edukacyjnych.

Analizując poziom wykonania zadania, warto wziąć pod uwagę czas przygotowania się przez badanych gimnazjalistów do wypowiedzi. Uczeń po otrzymaniu zadania miał możliwość przygotowania wypowiedzi (np. sporządzenia krótkiego planu, notatki itp.), o czym zapewniał go moderator prowadzący badanie, jednak blisko połowa uczniów nie skorzystała z tej sposobności. Czas przygotowywania się badanych do wypowiedzi ilustruje wykres 5 .

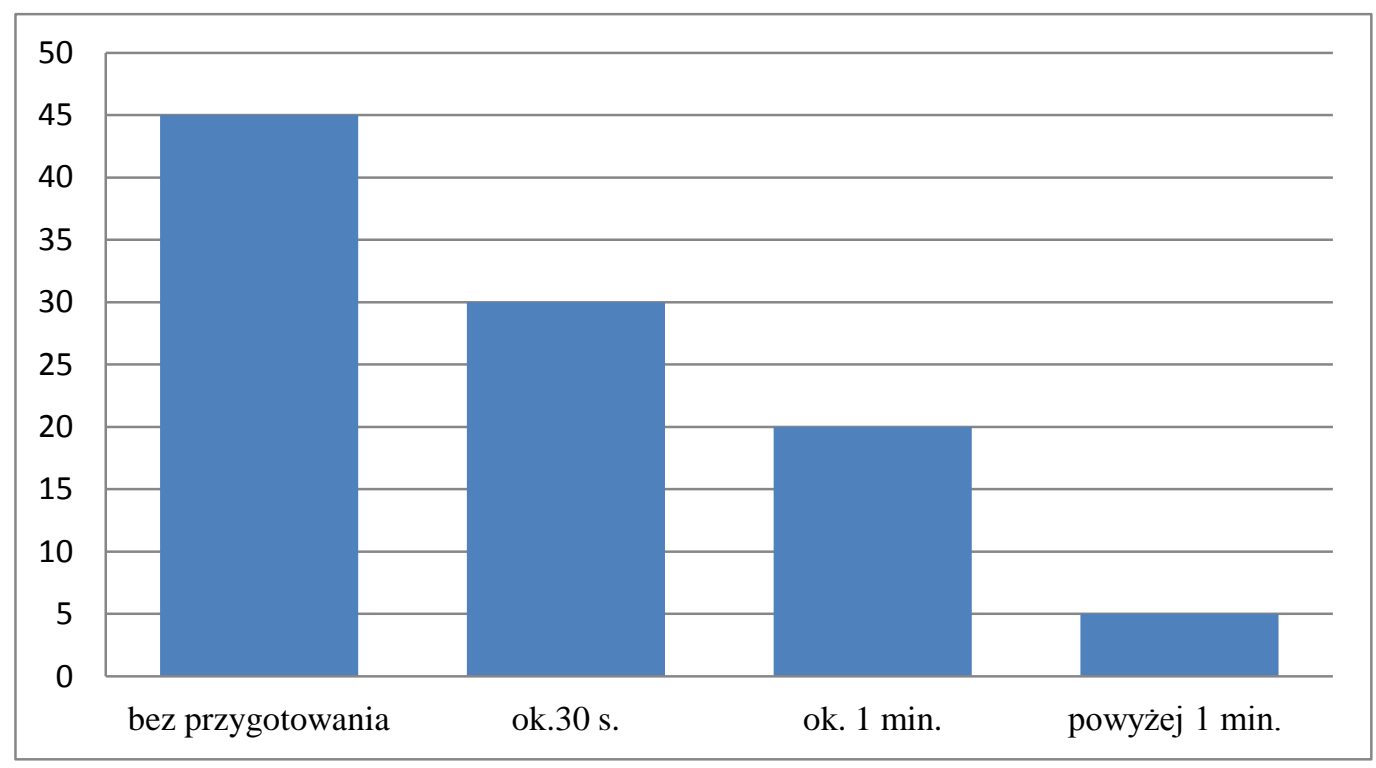

Wykres 5. Czas przygotowania ustnej wypowiedzi monologowej przez gimnazjalistów.

Z możliwości przygotowania się do wypowiedzi skorzystało 55\% uczniów. Sądząc jednak po pytaniach, jakie zadawali badani po usłyszeniu zadania, np. „Czyli o sporcie nie mogę mówić?”, częściej zastanawiali się nad wyborem tekstu niż nad argumentacją czy strukturą swojej wypowiedzi. Wydaje się również, że uczniowie z drugiej grupy, w której 
czas przygotowania wypowiedzi nie przekroczył 30 sekund, zdążyli jedynie przeczytać dość rozbudowane polecenie. Traktując obie grupy gimnazjalistów łącznie - tych, którzy odpowiadali od razu $(45 \%)$ oraz tych, którzy na przygotowanie wypowiedzi poświęcili ok. 30 sekund (30\%) - można stwierdzić, iż blisko 2/3 badanych uznało, że przygotowanie się do wypowiedzi ustnej jest zbędne.

Trudno zaproponować jednoznaczną interpretację tego zachowania, zwłaszcza że z przygotowania rezygnowali uczniowie zarówno z grupy słabszych, jak i uczniowie bardzo dobrzy. Można przyjąć, że albo uczeń uznał, że ma dużo do powiedzenia, potrafi płynnie mówić i dlatego nie widzi potrzeby przygotowania wypowiedzi lub odwrotnie: uczeń po przeczytaniu polecenia doszedł do wniosku, że nie ma za wiele do powiedzenia na zaproponowany temat, więc przygotowanie się do wypowiedzi nie wpłynie na jej jakość; albo gimnazjalista nie ma świadomości, że wypowiedź mówiona, podobnie jak pisana, powinna obok wartości merytorycznej spełniać inne wymogi, tj. być właściwie zorganizowana, spójna, mieć początek, rozwinięcie i zakończenie, pełnić odpowiednią funkcję itd.

Warto się również zastanowić, czy odpowiedź bez przygotowania nie jest ilustracją praktyk językowych stosowanych podczas lekcji. Wypowiadanie się uczniów bez głębszego zastanowienia wydaje się dość powszechnym zachowaniem komunikacyjnym. Jego źródłem może być częsta obecność na lekcjach języka polskiego metody heurystycznej (według raportu Instytutu Badań Edukacyjnych z 2014 roku heureza jest najczęściej stosowaną metodą na lekcjach języka polskiego). Metoda ta opiera się na pytaniach prostych, którym brakuje tylko jednego elementu mającego znaleźć się w odpowiedzi niewymagającej skomplikowanych procesów poznawczych, znajduje się w nich bowiem dostatecznie wiele danych, żeby na ich podstawie uczeń bez namysłu mógł wykryć brakujący element (Nagajowa 1990, 240).

Natychmiastowa odpowiedź nie służy też budowaniu nawyku analizowania tematu (zob. Jędrychowska 1993), polecenia, a ta czynność z pewnością wpłynęłaby na efektywność wypowiedzi zarówno pod kątem treści, jak i kompozycji, a może także na jej na efektowność.

Również podręczniki do nauczania języka polskiego (które stanowią jedno z podstawowych, choć, co trzeba podkreślić, nie jedyne narzędzie pracy nauczyciela) nie są wsparciem dla polonisty w kształceniu sprawności mówienia. Nawet pobieżna lektura wybranych tytułów pozwala na stwierdzenie, iż mówienie, jeżeli nie jest zaniedbywane, to przynajmniej nietraktowane priorytetowo. Analiza zadań dydaktycznych wskazuje, że sprawność ta jest kształcona w sposób dość przypadkowy i okazjonalny, zwłaszcza (co wydaje się zaskakujące) 
w częściach językowych podręczników, w których, co podkreśla Urszula Żydek-Bednarczuk, wiedza językoznawcza przetworzona na użytek szkolny powinna łączyć się ściśle ze sprawnościami i osiągnięciami w zakresie czytania, rozumienia, pisania i mówienia (ŻydekBednarczuk 2002, 137). Okazuje się, że zadań doskonalących sprawność mówienia jest niezwykle mało, a te, które są zaproponowane, mają charakter zadań krótkiej odpowiedzi, ich wykonanie sprowadza się do zbudowania przez ucznia wypowiedzi ledwie kilkuwyrazowej.

Podobnie w rozdziałach poświęconych gatunkom wypowiedzi zadań doskonalących mówienie jest niewiele. Autorzy podręczników pomijają w tych częściach sfery komunikacyjne „obsługiwane” przez typowe gatunki mówione. Jedyny obecny w podręcznikach przykład gatunku typowego dla sfery mówionej to dyskusja. Nie uwzględnia się również tego, że niektóre formy wypowiedzi mogą funkcjonować zarówno w odmianie pisanej, jak i ustnej, np. zaproszenie czy opowiadanie.

Wśród analizowanych zadań są i takie, których wykonanie, moim zdaniem, może wpłynąć na podniesienie poziomu sprawności mówienia. Przykładowe:

\footnotetext{
Przygotujcie sześć kartek i zapiszcie na nich nazwy różnych intencji wypowiedzi, np.: rozkaz, negacja, zachęta, przeprosiny, obietnica, rada. Utwórzcie sześć grup. Przedstawiciele zespołu losują po jednej kartce. Zadaniem każdej grupy jest ułożenie wypowiedzi zgodnie $\mathrm{z}$ wylosowaną intencją i wygłoszenie jej na forum klasy. Odgadnijcie intencje prezentowanych komunikatów. Ustalcie odpowiedź na pytanie: Dzięki czemu można rozpoznać intencje wypowiedzi? (Grabarczyk 2009, 10)
}

Celem tego typu ćwiczeń obok rozwijania umiejętności kluczowej - pracy w zespole jest doskonalenie sprawności mówienia i pogłębianie świadomości językowej. Uczniowie wykonujący zadanie znajdują się w sytuacji sprzyjającej mówieniu i mają możliwość uczestniczyć zarówno w interakcji nierównorzędnej, nieoficjalnej (rozmawiając między sobą, ustalając role, dyskutując nad wykonywanym zadaniem), jak i, prezentując na forum całej klasy w obecności nauczyciela, w interakcji nierównorzędnej w sytuacji oficjalnej. W ten sposób sprawność mówienia rozwijana jest w sposób całościowy, ponieważ obok aspektu merytorycznego realizowane są również aspekty: retoryczny, interakcyjny, kompozycyjny, stylowy, językowy, a także niewerbalny.

Wydaje się, że więcej zadań kształcących sprawność mówienia znajduje się w częściach literacko-kulturowych analizowanych podręczników. Przykładowo: 
Sformułuj swoje refleksje na temat wiersza, ilustrowane cytatami, zaczynając od słów: Moim zdaniem wiersz „Lasem” w sposób metaforyczny opowiada o... (przedstawia...) (Bobiński 2009, 25).

Przytoczona propozycja może być wykonana zarówno pisemnie, jak i ustnie, ponieważ twórcy zadania rezygnują z wprowadzenia wyraźnego sygnału sposobu jego realizacji. Wykonując ćwiczenie, uczeń musi zbudować dłuższą, uporządkowaną i spójną wypowiedź argumentacyjną na określony temat, w której istotnym aspektem jest warstwa merytoryczna. Dlatego można mówić, iż sprawność mówienia przy tego typie zadań rozwijana jest mimochodem, przy okazji, oczywiście pod warunkiem, że nauczyciel zwróci uwagę nie tylko na to, co uczeń mówi, ale również jak mówi. Warto przytoczyć przykład jeszcze innego zadania, w którym dzięki wyraźnemu wskazaniu ustnego sposobu jego wykonania oraz uwikłaniu w kontekst sytuacyjny, gimnazjalista ma możliwość rozwijania sprawności mówienia najefektywniejszą drogą - drogą wykonań językowych:

Porozmawiaj z pracownikiem schroniska dla zwierząt, które znajduje się w Twojej okolicy. Zaprezentuj wywiad na forum klasy (Chmiel i in. 2010, 11).

W ćwiczeniach doskonalących sprawność mówienia warto byłoby dostrzec ich potencjał integrujący treści polonistyczne. Według wielu dydaktyków elementem najmocniej scalającym treści nauczania przedmiotu język polski powinno być kształcenie językowe, zwłaszcza ćwiczenia doskonalące sprawność językową oraz gatunki wypowiedzi, które należałoby łączyć zarówno z lekturą, tekstami kultury, jak i nauką o języku, tak aby uczeń opanował odmianę mówioną i pisaną języka ojczystego.

Mimo iż badanie przeprowadzone zostało na niewielkiej grupie gimnazjalistów, przypuszczam, że jego wyniki są reprezentatywne - nieumiejętność tworzenia spójnej, uporządkowanej wypowiedzi to problem znacznie głębszy. Żyjemy w czasach ogromnych przeobrażeń kulturowych mających wpływ również na rzeczywistość językową. Jaką postawę przyjmuje wobec niej szkoła? Nie ma jednej trafnej odpowiedzi.

W szkolnym procesie nauczania-uczenia się kształcenie kompetencji komunikacyjnej leży w gestii wszystkich nauczycieli, jednak największa odpowiedzialność spoczywa na poloniście. Warunkiem opanowania sprawności mówienia jest „aktywność uczącej się jednostki: Mechanizm ten potwierdza angielską zasadę stosowaną w nauczaniu języków obcych: Speak now, learn later (Mów teraz, nauczysz się później). Dzisiejszy model szkoły mocno ogranicza aktywność uczniów. Sprowadzanie ich do roli odbiorców [...] niszczy motywację" (Żylińska 
2013, 87) do działania, również do mówienia. Innymi słowy, uczeń osiągnie wysoki poziom kompetencji komunikacyjnej tylko wówczas, gdy będzie miał warunki do tego, by mógł mówić - a przede wszystkim - by chciał mówić.

\section{Bibliografia}

Bobiński Witold, 2009, Świat w stowach i obrazach 1, Język polski. Podręcznik dla gimnazjum, Warszawa.

Chmiel Małgorzata, Herman Wilga, Pomirska Zofia, Doroszewski Piotr, 2010, Język polski dla klasy trzeciej. Stowa na czasie 3. Podręcznik do ksztatcenia kulturowego i literackiego, Warszawa.

Duszak Anna, 1998, Tekst, dyskurs, komunikacja międzykulturowa, Warszawa.

Grabarczyk Anna, 2009, Słowa na czasie. Podręcznik do kształcenia językowego z ćwiczeniami dla klasy pierwszej gimnazjum, Straszyn k. Gdańska.

Jędrychowska Maria, 1993, O analizie tematów wypracowań, „Polonistyka”, nr 6.

Kaniewska Maria, 1987, Prace pisemne z języka polskiego w średnich szkołach dla pracujacych, Warszawa.

Kowalikowa Jadwiga, 2001, Od tekstu cudzego do tekstu własnego. Retoryka odrodzona a koncepcja pracy nad doskonaleniem wypowiedzi pisemnej, w: Przybylska R., Przyczyna W. (red.), Retoryka dziś. Teoria i praktyka, Kraków, s. 511-519.

Nagajowa Maria, 1990, ABC metodyki języka polskiego, Warszawa.

Podracki Jerzy, 2013, Jak oceniać ustna wypowiedź maturalna, czyli o normie językowej w ,szkolnym” języku mówionym, „Polonistyka”, nr 10.

Śniatkowski Sławomir, 2002, Milczenie i pauza $w$ gramatyce nadawcy i odbiorcy. Ujęcie lingwoedukacyjne, Kraków.

Tabisz Anna, 2013, Od protojęzyka do sprawności mówienia, „Polonistyka”, nr 10.

Wiśniewska Halina, 2001, Substytucja tekstowa - uczniowska strategia pisania form wypowiedzi, w: Witosz B. (red.), Stylistyka a pragmatyka, Katowice.

Zgółkowa Halina, 2001, Retoryka w zreformowanej szkole. Diagnozy i perspektywy, w: Przybylska R., Przyczyna W. (red.), Retoryka dziś. Teoria i praktyka, Kraków, s. 489-501.

Szymanek Krzysztof, 2012, Sztuka argumentacji. Słownik terminologiczny, Warszawa.

Żydek-Bednarczuk Urszula, 2002, Koncepcja podręcznika do ksztatcenia językowego w gimnazjum, w: Kosętka H., Uryga Z. (red.), Podręcznik jako narzędzie kształcenia polonistycznego w gimnazjum, Kraków, s. 133-144.

Żylińska Marzena, 2013, Neurodydaktyka. Nauczanie i uczenie się przyjazne mózgowi, Toruń. 
Anna Tabisz - dr, lingwodydaktyczka, językoznawczyni, adiunkt w Zakładzie Polonistyki Stosowanej w Instytucie Polonistyki i Kulturoznawstwa Uniwersytetu Opolskiego. Zainteresowania badawcze mieszczą się w obrębie: lingwodydaktyki, lingwistyki tekstu, pragmalingwistyki oraz psycholingwistyki. Problemy szczegółowe, które podejmuje w badaniach własnych, to: komunikacja dydaktyczna, kształcenie językowe w szkole, kompetencja tekstotwórcza ucznia. Dorobek naukowy obejmuje monografię Kompetencje tekstotwórcze uczniów na przykładzie rozprawki (2006) oraz blisko trzydzieści artykułów naukowych. Jest współredaktorką tomów z serii „Język a Edukacja” (2013, 2014). 